\title{
Congressional Voting on Funding the International Financial Institutions
}

\author{
J. Lawrence Broz \\ Associate Professor \\ Department of Political Science \\ University of California, San Diego \\ jlbroz@ucsd.edu
}

Version 1.3

July, 2008

JEL Keyword Codes: F33, F42, F53, F55, F59

Acknowledgements: Delivered at the Conference on the Political Economy of International Organizations, Monte Verità, Switzerland, February 3-8, 2008. An earlier draft was presented at the 2007 Annual Meeting of the American Political Science Association, August 30th-September 2, 2007. I thank participants at both conferences, with special thanks to Nolan McCarty and Kenneth Schultz for discussant comments. I'm also grateful to Stephen Weymouth and Mark Farrales for research assistance. 
Title: "Congressional Voting on Funding the International Financial Institutions.”

\begin{abstract}
The United States is the largest contributor to the International Monetary Fund (IMF) and the World Bank, providing resources in exchange for voting power in these international financial institutions (IFIs). While the Treasury Department manages the day-to-day aspects of U.S. participation in these institutions, Congress retains authority on funding. With the aim of understanding the microincentives of U.S. support for the IFIs, I analyze congressional voting on bills to fund the IFIs. I argue that members of congress are more likely to support a funding increase (1) the more "liberal" their ideology, (2) the larger the share of campaign contributions they get from banks that specialize in international lending, and (3) the larger the share of voters that gain from economic globalization that reside in their districts. Statistical analyses of voting on five IFI funding bills since 1977 provide support for these arguments.
\end{abstract}




\section{Introduction}

The United States is a member of six international financial institutions: the IMF, the World Bank, the Asian Development Bank (AsDB), the African Development Bank (AfDB), the European Bank for Reconstruction and Development (EBRD), and the Inter-American Development Bank (IDB). Since 1945, the United States has contributed about $\$ 98$ billion to these institutions, and has pledged another $\$ 97$ billion in callable capital. ${ }^{1}$ Established by international agreements, the IFIs are embedded in the political systems of each member nation. In the United States, with its presidential system of government, Congress must give its consent before the U.S. takes part in an IFI funding agreement. While U.S. executive branch officials are influential actors within the IFIs, members of congress are powerful within the United States because they control U.S. appropriations for these institutions.

With the aim of understanding the microincentives of U.S. support for the IFIs, I analyze congressional voting on legislation to replenish the funds of the IFIs. The floor votes I explore are on bills, amendments, and motions in the House of Representatives that focus exclusively on funding the IFIs. There were five such votes between 1977 and $1998 .^{2}$ Three of these votes related to funding the IMF, one vote targeted the appropriation of funds for the World Bank, and one vote simultaneously funded the World Bank, its agencies, and the AsDB. Table 1 provides a summary of these votes.

${ }^{1}$ Callable capital is a legal obligation of the United States, to be exercised only if an IFI goes bankrupt and needs to pay off its bondholders. Only about 12 percent of the total callable capital has been appropriated. See Sanford (2005).

${ }^{2}$ On a number of other occasions Congress considered IFI funding increases in the context of large spending bills with thousands of allocations. On five occasions, however, members voted on amendments, motions, or bills that considered the IFI component separately from other allocations. 
A vote to increase funding to the IFIs signals support for the IFIs, since it increases the resources these organizations have for their international financial activities. My aim is to explain why some members of congress favor of such increases while others vote against them. My arguments and evidence suggest that voting is responsive to personal ideology, interest group influences, and district characteristics. I find that ideology has the largest impact on how members vote: conservatives are far more likely to oppose funding the IFIs than liberals, presumably because they view international institutions like the IMF and World Bank as remote and opaque bureaucracies that engage in wasteful interventions in the marketplace. The implication (which I explore in the conclusion of this article) is that a conservative U.S. Congress is likely to be a greater hurdle to funding the IFIs than a liberal one.

While ideology is an important influence on voting behavior, other factors also matter. In terms of interest group effects, I focus on campaign contributions from “money center” banks, which are large, commercial banks that specialize in international lending and are located in financial centers like New York, Chicago, and San Francisco. ${ }^{3}$ These banks have a special interest in supporting the IFIs - and the IMF in particular - because well funded IFIs mitigate the risks and promote the opportunities of lending to developing countries. If, for example, the IMF can help rescue countries when they face an economic crisis, there is a better chance that such countries will not default on loans they owe to these banks. I find that legislators that receive larger contributions from money center banks are more likely to vote in favor of increasing the U.S. contribution to the IFIs. I also find support, via a difference-in-difference test, that the

${ }^{3}$ Money center banks conduct a global wholesale business for clients that include governments, corporations, and other banks. Examples include Citigroup, J. P. Morgan Chase, and Bank of America. 
causal relationship runs from bank contributions to voting behavior, as in Stratmann (2002) and Kroszner and Stratmann (1998).

In addition to ideology and special interest contributions, legislators appear responsive to the preferences of unorganized constituencies in their districts. I argue that constituents view the IFIs as forces for global economic integration which, from the Stolper-Samuelson perspective, is good for high-skilled workers in the United States, but bad for low-skilled workers, who must compete with the low-skilled workers in developing countries. Alternatively, the Ricardo-Viner approach suggests that constituent divisions should fall along industry lines, with workers employed in import-competing industries opposing the IFIs globalizing policies, and workers involved in exporting industries favoring them. I find support for the Stolper-Samuelson perspective.

The effects of ideology, campaign contributions from international banks, and district skill level are large and statistically significant, even when I control for party affiliation (which is correlated with ideology but may represent a different influence on voting) and district income (which correlates with skill level but suggests an alternative interpretation). The strength of these findings indicates that the United States does not act as a singular entity regarding the IFIs. While there are members within Congress that are obstacles to funding increases for the IFIs, there are also members that are allies of these institutions--those who want to give the IFIs more resources and more authority to stabilize world financial markets and to promote economic development. I examine the battle that occurs within Congress because, depending upon who wins it, Congress can be just as much an ally as an obstacle to the IFIs.

The paper is organized as follows. In Section 2, I provide a summary of the functions and funding arrangements of the IFIs, as well as an institutional rationale for focusing on the 
preferences of U.S. legislators. Section 3 contains my arguments and evidentiary strategy, and Section 4 is the empirical analysis of congressional roll-call votes. The final section is the conclusion, which discusses implications.

\section{Political Institutions and the Funding of the IFIs}

The motivation for this Congress-centric project rests on the following syllogism: if the United States is powerful within the international financial institutions and, if Congress is powerful within the United States, then the preferences of members of congress are important to the IFIs. With respect to influence within the IFIs, voting rules tell most of the story. In all the IFIs, voting is weighted by the capital contributions of member governments, which gives the largest contributor - usually, the United States - the greatest say in how the IFIs are run. With respect to influence over IFI policy within member countries, the United States is the only major IFI member with a presidential political system, which gives the Congress significant control over IFI policy. This section describes the functions and governance structures of the IFIs, as well as the features of the U.S. political system that position Congress at the center of IFI policy.

The functions of the IFIs fall into two distinct categories: balance of payments financing and long-term development assistance. These functions reflect the division of labor between the IMF and the World Bank at their founding in 1945 (Horsefield 1969). The IMF's mandate was to support global trade and economic growth by providing assistance to countries facing balanceof-payments difficulties. The principal function of the World Bank was to provide development loans for projects that were too large or too risky for private banks to finance. Development and poverty alleviation remain the stated objectives of the World Bank, which make it a "Multilateral Development Bank” (MDB). Its lending is done through the International Bank for 
Reconstruction and Development (IBRD) and the International Development Association (IDA). ${ }^{4}$

The IBRD was the first MDB and remains the largest, providing over half of all MDB assistance. In 1959, the Inter-American Development Bank (IDB) was created in response to a pressure from Latin American countries for a development bank that would be attentive to regional needs. The African Development Bank (AFDB) was established in 1964 and was, until 1983, an African-only institution. The Asian Development Bank (ADB) was created in 1966 to promote regional cooperation. The European Bank for Reconstruction and Development (EBRD) was founded in 1991 to promote market-oriented reform in the former communist countries of Eastern Europe and the former USSR.

Since the debt crisis of the early 1980s, the roles of the IMF and the World Bank have converged. When debtor nations were unable to meet their debt-service obligations, the World Bank added conditionality to its lending. The IMF, in turn, began to play a major role in structural adjustment through increased medium- and long-term lending and the institutions began to cooperate on short- and medium-term program lending. By the 1990's, the functions of the IMF had converged with those of the World Bank, albeit with the IMF retaining sole authority for balance-of-payments financing.

While the functions of the IMF and World Bank have converged over time, funding and governance arrangements have not evolved significantly in any of the IFIs since their founding. Moreover, the process of negotiating and authorizing a new funding plan is largely the same across all IFIs. For the IMF and most World Bank agencies, member countries make

\footnotetext{
${ }^{4}$ IBRD loans are made with favorable interest rates and long repayment schedules. IDA credits are extended to very poor countries at no interest and with relaxed loan repayment schedules.
} 
contributions only when they believe the agency's capital base needs expansion. ${ }^{5}$ These expansions are negotiated within the executive boards of the IFIs, with a presidentially appointed U.S. executive director representing the United States point of view. In some cases, a supermajority of votes - 85 percent in the case of the IMF - is required to put the plan into effect. Since the U.S. share of votes has always been greater than 15 percent, the U.S. can veto any funding plan it opposes.

More generally, voting power within the IFIs is proportionate to contributions, which creates a strong inducement for governments to contribute (Blomberg and Broz, 2007). The result is a weighted voting governance system in which the IFIs are largely under the control of the major powers. The United States is the largest contributor to the IMF and World Bank, which buys it about 17 percent of the voting power in these institutions. Actual U.S. influence is greater than its vote share because major policy changes, like funding increases, require an 85 percent supermajority.

Table 2 lists the current voting shares of the five largest contributors to the IFIs. The United States has the largest vote share in the IMF, the World Bank, the IDB, the EBRD, the AsDB (with Japan), and is second to Nigeria in the AfDB. Furthermore, the U.S. has veto power over core decisions - changes in contributions/vote shares and other constitutional issues - that require supermajority votes in the IMF, World Bank, and IDB.

In testimony to Congress in 1981, Treasury official Marc Leland acknowledged that the weighted voting system is essential to U.S. participation in the IFIs: "If I were convinced that these institutions were run on one-man, one-vote principles, I would be skeptical about idea of

\footnotetext{
${ }^{5}$ For the IDA and other similar MBDs, Congress appropriates funds annually to pay for the U.S. share of the refunding plan.
} 
going along and supporting them. I am frank about that, but they are not run on that basis...if you just abstract the idea of creating an international institution situated in Washington, DC, in which we are the only ones with a veto and over which we, together with our allies, have the commanding influence and by working together we can get the objectives we want, I think you would still create that kind of institution" (U.S. Congress 1981, 563).

The voting system empowers the United States, and other G5 countries, within the IFIs. But whose preferences shape policy toward the IFIs within these powerful member nations? I make the simple point that the type of political system - presidential or parliamentary determines whose preferences matter within major member countries. The U.S. has a presidential system, also called a congressional system, wherein power is divided between the executive and the legislative branches. The U.S. represents the strongest form of presidentialism, in the sense that the election and the survival of officials in each branch are completely separate. One consequence of presidentialism is that the legislature has significant control over policy. Hence, if the U.S. executive wants to pursue a certain IFI policy, it must attain the consent of the legislature. In parliamentary systems, by contrast, when the executive decides IFI policy, it does not need to clear it with the legislature. This is because executives and legislatures are closely conjoined in parliamentary systems via rules of selection and survival for officials in each branch that are closely linked. The consequence is that power is concentrated in parliamentary systems and executives rule with the entire weight of parliament behind them. Hence, IFI members with parliamentary systems do not need legislative approval to pursue their IFI policies.

In the United States, legislative authorization is necessary for the U.S. to participate in a new IFI funding plan. Since 1977, Congress has authorized the United States to participate in 
eight funding increases of the World Bank's IDA, two capital increases of the IBRD, five increases for the IMF, and several capital increases or replenishments of the other IFIs (Sanford 2005). In most instances, the authorization legislation was included in another measure: a larger omnibus appropriations act, the annual foreign operations appropriations bill, or a budget reconciliation bill. ${ }^{6}$ These large appropriations bills are not suitable for analysis because IFI funding is wrapped together with other appropriations, making it impossible to isolate legislator positions on this single issue. However, on five occasions Congress voted on legislation dedicated exclusively to IFI funding.

Two of these cases were freestanding bills that followed the regular order process: HR 5262 in the $95^{\text {th }}$ Congress and HR 7244 in the $96^{\text {th }}$ Congress. HR 5262 increased U.S. funding for the IBRD, the IDA, and the ADB; it passed in the House by a vote of 194-156 on April 4, 1977. HR 7244 amended the Bretton Woods Agreements Act to authorize the U.S. Executive Director at the IMF to consent to an increase in the U.S. contribution to the Fund in advance of appropriations; it passed by a vote of 191-151 on September 18, 1980. Two others votes were amendments to larger appropriations acts that dealt only with IFI funding: H.AMDT 306 to HR 2957 (98th Congress), and H.AMDT 115 to HR 2295 (103 ${ }^{\text {rd }}$ Congress). H.AMDT 306 came during the Latin American debt crisis, which provoked worries among some conservatives that a new contribution to the IMF would fund a bailout of commercial banks (Bordo and James 2000: 32). The amendment sought to strip the larger spending bill of the IMF replenishment; it failed by a vote of 182-227 on July 27, 1983. H.AMDT 115 was sponsored by Republican John Kasich

\footnotetext{
${ }^{6}$ On several occasions, the authorizations were protected from floor amendments by way of special rules or parliamentary procedures.
} 
(OH-12) during the 1993 debate about replenishing the funds of the World Bank. It would have eliminated the $\$ 55$ million allocation to the Bank, but failed narrowly by a vote of $210-213$.

The Asian financial crisis of 1997-98 provided the backdrop for the fifth vote. Congress was involved in intense debate over the merits of IMF actions during the crisis, delaying passage of an emergency spending bill (HR 3579) that included \$18 billion in new funding for the IMF. The vote was on a motion to instruct the House conferees to agree to the administration's request for funding of the IMF under the terms and conditions approved by the House Banking Committee, thereby reconciling two versions of the bill. It failed 186-222 on April 23, 1998, stalling the appropriation of funds for the IMF another six months.

The roll call votes on this legislation provide an opportunity to estimate the covariates of member support for the IFIs. They are "clean" in the sense that a vote for or against captures a member's position on increasing U.S. contributions to the IFIs. However, because these votes were handled differently than other IFI funding increases, they may not be representative of typical congressional voting on the issue. For example, the context of international financial crisis surrounding votes in 1980, 1983, and 1998 is probably not representative of the universe of cases. On the other hand, analyzing this subset of IFI voting can yield useful inferences because the positions of legislators--and the underlying cleavages that drive these positions--are thrown into sharp relief by the crises. Table $\mathbf{1}$ provides a summary of the five votes in the sample.

\section{Approach and Arguments}

Which members of congress will vote in favor of IFI funding increases? Which will vote against? While previous studies of IFI voting do not exist, work on congressional voting behavior more generally suggests a baseline model in which voting is considered to be a function of ideology, party, and constituency influences (e.g. Ansolabehere, Snyder, and Stewart 2001, 
Bailey and Brady 1998). I use this baseline approach to identify specific hypotheses regarding voting behavior in the IFI policy area.

In the standard approach, legislator voting behavior is assumed to be self-interested and driven by legislators' desire to remain in office. But because IFI policy is not a high salience issue--of concern to most voters, most of the time--legislators have some flexibility to vote their personal convictions. As the average voter is not likely to be aware of most IFI legislation, legislators need not be perfect agents of constituent preferences and will have room to vote their personal beliefs (Miller and Stokes 1963). What, then, shapes legislator beliefs about the IFIs?

I argue that ideology provides legislators with a simple schema for evaluating policy towards the IFIs. Indeed, almost all issues in Congress fall on a single liberal-conservative dimension epitomized by the role of government in the economy (Poole and Rosenthal 1997). Funding the IMF or the World Bank should be no different. Conservative politicians that believe in a small role for government regulation of the domestic economy should oppose financing the IFIs because IFI programs distort economic incentives in the global economy. In fact, many conservatives see IMF programs as "bailouts" that insulate investors and borrowers from the risks of their actions and thereby promote greater instability in international finance. Conservatives also oppose the expansion of the government sector and see international organizations like the IMF as particular prone to waste and inefficiency. ${ }^{7}$

Conversely, liberals focus on market failures at both the domestic and the international levels and see a positive role for IFIs in mitigating the economic and social costs of financial and development crises. They also tend to be more optimistic about the operations of international

${ }^{7}$ See, for example, Dick Armey (Rep, TX), “The Moral Hazard of IMF Expansion.” Remarks as prepared for delivery on the House Floor, October 2, 1998. 
organizations, and the motivations of the officials that inhabit them. ${ }^{8}$ In short, ideology provides the foundation upon which legislators evaluate the IFIs.

To illustrate the argument, consider the debate over the Meltzer Commission Report, produced in November 1998, by the International Financial Institution Advisory Commission. ${ }^{9}$ The Meltzer Commission, named for its chair, economics professor Allan Meltzer, was established by Congress as part of legislation authorizing $\$ 18$ billion of U.S. funding for the IMF to aid in resolving the Asian currency crises. Instructed to consider the efficacy of the IFIs, the conservative majority on the Commission, led by Meltzer, won the day over the more liberal minority, as pointed out in dissenting statements by C. Fred Bergsten and Jerome Levinson. Conservative proponents of the Commission's recommendations supported reduced roles for the IFIs, noting that banks and borrowing countries use the IMF to bail them out of economic crises, thereby creating a moral hazard problem. Liberals took a negative view of the Report, finding the recommendations extreme, ill-grounded in theory and history, and cast prejudicially against the IFIs. The liberal side argued that the IFIs have a necessary and important place in the world economy, due to market failures in international finance and development, and that the approach taken by the Commission’s conservative majority effectively "eviscerated” them.

While ideology should influence voting on the IFIs, legislators are not completely unconstrained to vote their beliefs. To some degree, they must also consider how their votes on the IFI funding will affect them electorally, which means they have to be sensitive to the

${ }^{8}$ See, for example, John J. LaFalce, (Dem, NY), "The Role of the United States and the IMF in the Asian Financial Crisis," Address before the Institute for International Economics, Washington, DC, January 27, 1998. See also Locke (2000).

${ }^{9}$ See Meltzer (1998) for a conservative statement on the IMF's handling of the Asian crises. 
preferences of district constituents, whose votes are needed to stay in office, and special interest groups, who contribute money to legislators’ campaigns.

With respect to constituent preferences, I expect members representing districts with greater proportions of net "winners" from economic globalization to be more likely to favor increasing the IFI's resources. This is because the IFIs, by pursuing their mandates to promote the expansion, integration, and stability of the global economy, encourage globalization and its attendant domestic distributional consequences. Promoting openness to trade and foreign direct investment are, in fact, core mandates of the IFIs and, as Woods $(2006,2)$ argues, the "greatest success of the IMF and the World Bank has been as globalizers.”

Two models from trade theory identify the winners and losers of the IFI's proglobalization policies: the Ricardo-Viner model and the Stolper-Samuelson model. The RicardoViner model assumes that factors of production are stuck in their current industry, due to high costs of exit (e.g., relocation, retooling, and retaining costs). This implies that the incomes of all factor owners in an industry rise or fall together. When an export industry expands due to trade, the need for these industry specific factors expands as well, and they become more valuable. Their owners therefore gain. But, for industries that contract due to import competition, the owners of specific factors find their skills or their property obsolete, and they may suffer a significant loss of real income. In short, the divisions on globalization fall along industry lines, with workers and owners in export industries gaining while workers and owners in importcompeting industries lose.

Stolper and Samuelson (1941) and Mundell (1957) identified globalization’s winners and losers from a model in which factors of production are assumed to be freely mobile across industries. This yields the prediction that owners of locally abundant factors tend to gain more 
than average from globalization, while owners of scarce factors tend to lose, regardless of the sector in which they are employed. In the United States, the relatively scarce factor is lowskilled labor, and thus the group most likely to lose from globalization is low-skilled labor (Wood 1994). As trade has increased with nations where low-skilled labor is relatively abundant (and hence cheap), labor in the U.S. has indeed mobilized against globalization, and received protection in less-skilled intensive industries in return (Haskel and Slaughter 2000; Baldwin and Magee, 2000). By contrast, highly skilled labor is abundant in the U.S. relative to the rest of the world and thereby benefits from globalization. Analysis of public opinion survey data provide support for the argument: workers with college degrees or high skills support further liberalization of international trade and investment while those with less education and fewer skills resist such initiatives (Scheve and Slaughter 2001, O’Rourke 2003, Mayda and Rodrik 2005).

My extension of trade theory to IFI funding recognizes that the IMF's mandate to protect the world economy from financial disorder, and the MDB's mandate to promote development via integration with the world economy, is a benefit to U.S. voters that gain from global economic integration. From the Ricardo-Viner perspective, I thus expect legislators with higher shares of constituents employed in export industries to be more receptive to IFI funding increases than members with large numbers of workers employed in import-competing industries. From the Stolper-Samuelson perspective, I expect members representing districts with greater proportions of highly-skilled workers to support IFI funding increases, while legislators with greater shares of low-skilled workers in their districts will oppose these appropriations.

Inasmuch as legislators evaluate the distributional effects of a policy on voting constituencies within their districts and take positions that reflect these interests, diffuse interests 
such as high- and low-skilled workers or workers in import-competing and export industries, may find their interests expressed in the electoral calculations of legislators (Bailey 2001; Arnold 1992; Denzau and Munger 1986). These calculations can occur even in the absence of direct influence and lobbying, meaning that diffuse interests don't actually have to organize for this mechanism to be effective.

Among organized interest groups, money center banks comprise a key constituency for the IFIs. On the one hand, IMF financial rescues provide de facto insurance to these banks, allowing them to retain the gains from international lending while distributing losses, when they occur, to the public sector. On the other, the pro-globalization orientation of the World Bank and other MDBs expands international opportunities for these banks and promotes policies in developing countries that are conducive to debt repayment. Thus, I expect campaign contributions from money center banks to have a positive impact on the propensity of a legislator to vote in favor of increasing U.S. contributions to the IFIs. ${ }^{10}$

Of all the IFIs, the IMF is most directly beneficial to these banks. Even if intended to stabilize the international financial system, IMF rescues are a form of insurance for private creditors, and thus a source of moral hazard (Bulow and Rogoff 1990, Rogoff 1999). Moral hazard arises when the existence of IMF crisis assistance encourages banks to take on risks that they might otherwise shun, in an attempt to reap greater financial returns. Banks may over-lend to emerging economies because of the expectation, based on previous experience, that the IMF

\footnotetext{
${ }^{10}$ Endogeneity is a potential concern here as special interests may give contributions to members that already share their policy positions, rather than to "buy their votes" (Ansolabehere, de Figueiredo, and Snyder 2003; Hall and Wayman 1990). To establish causality running from campaign contributions to voting behavior, I employ Stratmann's (2002) “difference-indifference" method, which exploits the panel feature of my data to test whether changes in member voting behavior over time are related to changes in contributions from banks.
} 
will provide the foreign exchange liquidity that will allow them to exit the country in time of crisis, without bearing their full losses. Indeed, Bird $(1996,489)$ finds that the financial assistance the Fund provides to debtor countries is often used to repay loans to commercial banks. In fact, in some instances, debt service is an explicit component of IMF programs. ${ }^{11}$ Demirguc-Kunt and Huizinga (1993) also find more general evidence of the benefits moral hazard provides to banks by showing that unanticipated increases in U.S. financial commitments to the IMF cause the stock market capitalization of the exposed banks to increase.

My argument is that commercial banks with assets in developing countries are the most direct beneficiaries of IMF-created moral hazard and therefore likely to give campaign contributions to legislators that support funding the IMF. While the activities of the World Bank and other MDBs also benefit international banks, the gains are less direct and work through structural adjustment policies that encourage developing countries to pursue openness to international capital and trade flows.

\section{Data, Models, and Results}

I test the following three hypotheses: First, I expect legislators with conservative ideologies to oppose new funding requests for the IFIs. Conservative members oppose IFI funding because they see the IFIs as opaque, inefficient bureaucracies whose interventions in global financial markets and in development are wasteful, distortionary, and a source of moral hazard. My measure of legislator ideology is the first dimension of the DW-Nominate score (Poole and Rosenthal 1997). DW-NOMINATE ranges from -1 to +1 , from most liberal to most

${ }^{11}$ Broz and Hawes (2006) and Oatley and Yackee (2004) find that countries in which U.S. money center banks are more heavily exposed are more likely to receive support from the IMF, controlling for other correlates. 
conservative, and is based on members' voting behavior on issues related to government intervention in the economy.

In estimating the effect of personal ideology, I control for legislators’ political party affiliation on the grounds that party and ideology are highly correlated but may represent a distinct causal process. ${ }^{12}$ Many studies find that a party affiliation is an important independent predictor of legislative voting behavior, due to systematic differences in inter-party constituencies (e.g. Froman 1963, Clausen 1973, Bailey and Brady 1998). It is well know, for example, that Republican legislators tend to be more likely to represent big business constituents than Democrats. Conversely, Democrats tend to draw disproportionately from labor unions for support. Since labor unions are, on average, opposed to globalization while big businesses (multinational corporations and major exporters) tend to support globalization, I expect Republican legislators to be more likely than Democrats to favor the IFIs. I use an indicator variable for political party affiliation, PARTY, which takes the value of " 1 " if the legislator is a Republican Party and “0” if a Democrat.

Distributional reasoning stands behind my second hypothesis, which is that the higher the share of voters in a district that benefit from global economic integration, the more likely a member will be to support the IFIs. The beneficiaries can be defined by industry, following Ricardo-Viner reasoning, or by skill level following Stolper-Samuelson. Either operationalization captures my argument that legislators understand that the IFIs promote globalization, and take positions that reflect the impact of globalization on the real incomes of their constituents.

12 The simple correlation between DW-NOMINATE and PARTY is $r=.87$. See Table 3 for the full correlation matrix. 
My proxies for the Ricardo-Viner effect are NET IMPORTS and NET EXPORTS. NET IMPORTS is the percentage of district workers employed in manufacturing industries where the ratio of imports to consumption is greater that the ratio of revenues from exports to total industry revenue. NET EXPORTS is the percentage of workers in sectors where the ratio of revenues from exports to total industry revenue is greater than the ratio of imports to consumption (see the Data Appendix for more details). To model Stolper-Samuelson effects, in which I posit a positive relationship between constituent skill levels and legislator support for the IFIs, I use COLLEGE, which is the share of district population aged 25 and above with four years or more of college.

My third hypothesis is that voting behavior is positively associated with a member's affinity to money center banks. These banks comprise the special interest group with perhaps the most to gain from well-funded IFIs. I proxy legislator affinity to this interest group by the amount of campaign contributions members receive from these banks. To identify money center banks, I use the regulatory classification in the Federal Financial Institutions Examination Council's (FFIEC) "Country Exposure Lending Survey.” Because the FFIEC identifies the specific banks that comprise the money center group, I was able to obtain a list on which to base the collection of campaign contribution data (see the Data Appendix for the banks that make up this group). For campaign contributions, I use the Federal Election Commission's data on contributions from Political Action Committees (PACs). My constructed variable is BANK PAC: the sum total of money center bank contributions to each House member in the previous electoral cycle. The value of contributions is divided by 1,000 for ease of interpretation.

Table 4 presents results of probit analyses of IFI voting behavior on a pool of votes. Models 1 and 2 pools votes on all five IFI funding bills listed in Table 1. In Models 3-5, voting 
on HR 5262 (1977) drops from the analysis because contributions data for BANK PAC are not available for this vote. The dependant variable equals " 1 " if a member votes in favor of IFI funding, "0" otherwise ("nay" votes on H.AMDT 306 and H.AMDT 115 were coded "1" since a vote against these amendments is a vote in favor of funding the IFIs). I introduce the independent variables sequentially from Model 1 to Model 5 to assess multicolinearity concerns. $^{13}$ Model 5 is the full model, which controls for district affluence with MEDIAN INCOME, which is median household income in a district. It is important to control for a district affluence because it correlate strongly with district skill level $(r=.75)$ but potentially picks up a different influence on voting behavior. Whereas skill level is meant to capture the distributional effects of the Stolper-Samuelson model, affluence suggests an altruistic motivation: more affluent constituents may be more supportive of IFI funding because they can better afford income transfers to developing countries than voters with lower socio-economic status. ${ }^{14}$

Across all model specifications in Table 4, legislator ideology is strongly associated with voting behavior: the negative and highly significant estimate for DW-NOMINATE suggests that conservative legislators are indeed more likely to oppose financing the IFIs. This result is robust to the inclusion of political party affiliation (PARTY) in Models 2-5. The positive sign on PARTY indicates that Republicans are more likely to support the IFIs than Democrats (once personal ideology is taken into account). This finding may reflect the fact that Republicans are more responsive to pro-globalization business interests in their districts while Democrats have

13 PARTY and DW-NOMINATE are highly correlated $(r=0.87)$, as are COLLEGE and MEDIAN INCOME $(r=0.75)$. See Table 3 for the correlation matrix.

14 Some research suggests that foreign aid is a normal good, meaning that support for aid to developing countries rises with income (Krueger 1996). 
strong, historic ties to anti-globalization labor unions, as in Bailey and Brady (1998). With respect to multicolinearity between PARTY and DW-NOMINATE, I ran models with and without DW-NOMINATE (not reported). Dropping the measure of ideology produces a coefficient estimate for PARTY that is negative and highly significant, indicating that Republicans are less likely to support the IFIs when ideology is not considered. This makes sense since party affiliation correlates strongly with ideology. However, models that include only PARTY fit the data far less well (Pseudo $\mathrm{R}^{2}=0.21$ ) than models that include both DWNOMINATE and PARTY (Pseudo $\mathrm{R}^{2}=0.39$ ). These tests suggest that both variables are important and that each captures a unique aspect of voting behavior.

The results in Table 4 also support a link between legislator voting and special interest lobbying via campaign contributions. The estimate for BANK PAC is positive and highly significant in Models 3-5, suggesting that contributions from money center bank PACs increase the likelihood that a legislator will vote in favor of funding the IFIs, as expected.

Models 4 and 5 provide evidence in support of the Stolper-Samuelson globalization effect as the positive and highly significant estimates on COLLEGE indicate that members with larger shares of high skilled constituents in their districts tend to support IFI funding legislation. This result is robust to the inclusion of DISTRICT INCOME (Model 5), which I include on the grounds that constituents from more affluent districts might be more generous, with respect to spending on IFI projects in poor countries, or more cosmopolitan about the need for the IFIs in world affairs. While COLLEGE and DISTRICT INCOME correlate at $r=0.75$, the estimate for COLLEGE remains positive and significant in Model 5, suggesting that the Stolper-Samuelson effect operates independently of district socio-economic status. 
Models 3-5 provide little evidence in support of Ricardo-Viner effects, however. NET IMPORTS has the wrong sign (but is not significant) and NET EXPORTS is not significant (although it has a p-value of 0.15). Thus, legislators with higher proportions of workers employed in net import-competing industries appear no more likely to vote against IFI funding than members from districts with less exposure to imports. While members from districts with higher shares of workers in net export industries might be more likely to vote in favor of the IFIs than members with fewer exporting industries in their districts, this relationship may be due to chance.

As the substantive meaning of the probit estimates in Table 4 are difficult to interpret, I use the "Clarify" software (Tomz et al 1998; King et al 2000) to simulate the predicted probability of observing a vote in favor of IFI funding for both Democrats and Republicans, and then examine how these probabilities change as each explanatory variable is increased by one standard deviation above its mean. I ran the full model (Model 5) in Table 4 to estimate these predicted probabilities, which are reported in Table 5. The impact of ideology is substantively very large: a 1 standard deviation increase in DW-NOMINATE above its mean reduces the likelihood of a Republican supporting the IFIs by 60 percentage points. The effect of increasing conservatism is also large for Democrats: a 1 standard deviation increase in conservatism reduces the likelihood that a Democrat will vote in favor of IFI funding by 32 percentage points.

These are impressively large effects. There is, however, a notable difference in the sensitively of Republicans and Democrats to ideology: by these estimates, conservatism has nearly twice the impact on Republicans than it has on Democrats. This partisan gap is consistent with research demonstrating that members of the two parties respond differently to various subconstituencies in their districts, as in Bailey and Brady (1998). In respect to the IFIs, the 
corporate sector--a traditional Republican constituency--tends to support the globalizing activities of the IFI while labor union members--a traditional constituency of Democrats--tend to oppose these activities due to concerns about globalization's negative impact on wages and job security. Hence, ideology may affect Democrats less intensely than Republicans because Democrats are already predisposed to oppose the IFIs while Republicans are predisposed to support them. In other words, ideology may have a stronger impact on congressional voting behavior when it cuts against traditional partisan allegiances.

Table 5 also reports large, highly significant substantive effects for COLLEGE and BANK PAC. Increasing the share of a member's congressional district population with four or more years of college by one stand deviation increases the chance that a member will cote in support of the IFIs by 13 percentage points for Democrats and 9 percentage points for Republicans. Increasing campaign contributions from international banks by a standard deviation hikes the probability that a Democrat will support the IFIs by 7 percentage points, while the same change in contributions to a Republican yields a 5 percentage point increase in the likelihood of voting in favor of the IFIs. Again, the partisan difference in the responsiveness of legislators to the skill level of their districts and campaign contributions from money center banks may reflect the fact that Democrats have had an historic and populist distrust of both globalization and banks, so that district skill level and campaign money from banks have a larger impact on Democrats than on Republicans.

In contrast to district skill levels, the magnitudes of the Ricardo-Viner effects, NET IMPORTS and NET EXPORTS, are small and insignificant. Furthermore, the positive sign on NET IMPORTS works against this globalization hypothesis since the prediction is that members 
from districts with larger numbers of workers employed in import-competing industries will tend to oppose the IFIs.

Pooling votes on non-identical legislation over a 20 year period may obscure the effects of the context in which each vote took place. To allow for a comparison across votes and to identify any contextual differences that may be hidden in the pooled results, I present results for each individual vote in Table 6. All models contain the full set of independent variables and controls from Model 5 in Table 4. A comparison across votes reveals that context plays little role with respect to member ideology and campaign contributions from international banks: DWNOMINATE and BANK PAC are properly signed and highly significant in every regression. Likewise, PARTY and COLLEGE, show few differences across the votes: each variable is correctly signed in 4 of the 5 votes and significant in 3 votes. While NET EXPORTS is positively signed in 4 of 5 votes, as expected, it is significant in 2 votes, and NET IMPORTS is negative in 3 of 5 votes and significant in only 1 vote. Overall, the results in Table 6 suggest that voting behavior on IFI bills reflects four influences consistently over time and across contexts: personal ideology, party affiliation, campaign contributions from international banks, and district skill level. The inconsistency in the estimates of Ricardo-Viner effects may reflect contextual differences (as in whether the vote took place during an international financial crisis or not), but I can see no systematic patterns in these results. Measurement error may also play a role since NET IMPORTS and NET EXPORTS are crudely constructed from county-level, as opposed to congressional-level, data (see the Data Appendix).

As mentioned above, endogeneity may complicate the interpretation of BANK PAC. My hypothesis is that campaign contributions from money center banks increases the likelihood that a legislator will vote in support of the IFIs. This argument has causality running from bank 
contributions to legislator voting behavior. However, if money center banks give money to legislators that would support them anyway, then a positive correlation between BANK PAC and IFI voting does not justify the conclusion that bank money influenced votes in Congress. The correlation may arise because the same underlying factors that caused members to vote in support of the IFIs also caused banks to contribute to legislator campaigns.

Stratmann (2002) has developed a "difference-in-difference” method for overcoming the simultaneous-determination bias inherent in the contributions-votes relationship. ${ }^{15}$ The method exploits the panel feature of the data to test whether changes in member voting behavior over time are influenced by changes in contributions from special interest groups. This research design requires the existence of votes taken at different points on the same (or similar) issues. It also requires that at least some legislators changed their votes on the issue over time, for if no change in voting behavior occurred, there is no variance to be explained by changes in PAC contributions.

In my data, 588 legislators voted on more than one IFI funding bill. Of this number, 422 (72 percent) did not change their positions, always voting "yea” or "nay” on IFI funding bills. This high percentage of non-switchers suggests that the votes in my sample are broadly similar. But because there is no time-series variation in the positions of these 422 non-switchers, they cannot contribute to analysis of the influence of bank money on voting. However, 166 members (28 percent) did change there positions on IFI funding over time. These observations comprise the difference-in-difference test: do increases (decreases) in contributions from money center

\footnotetext{
${ }^{15}$ Broz (2005) uses this approach to show that changes in contributions from money center banks sways member voting on a closely related issue: international financial rescues provided by the U.S. Treasury’s Exchange Stabilization Fund
} 
banks increase (decrease) the probability that a member will switch positions to favor (oppose) IFI funding?

Following Stratmann (2002), Table 7 presents the results of a conditional (fixed effects) logit analysis of changes in legislator voting behavior over time. There are 166 instances in which individual legislators switched their votes on IFI funding in the panel, which includes three votes: H.AMDT 306, H.AMDT 115, and the Motion on HR 3579. The vote on HR 7244 in 1980 serves as the benchmark with respect to identifying the positions of legislators and contribution levels from banks. A dependent variable value of "1" indicates a vote switch in favor of IFI funding legislation, "0" indicates a vote switch to oppose IFI funding. This is a fixed effects model wherein a legislator indicator variable controls for omitted variables that are constant over time for each legislator. BANK PAC reflects contribution levels from the previous electoral cycle; DW-NOMINATE and COLLEGE values are for the current year. Conditional Logit is a difference estimator that measures the impact of changes in all time-varying explanatory variables on change in voting behavior. Since legislator party affiliation (PARTY) is time invariant, it is omitted from the model. ${ }^{16}$

The estimates on BANK PAC in Table 7 suggest that changes in bank contributions do influence changes in voting behavior. In Model 1, the coefficient is positive and nearly significant, with a p-value of 0.11 , and in Model 2 BANK PAC is significant. The implication is that, for the 166 cases in which House members switched votes between 1983 and 1998, an increase in bank contributions from previous electoral cycle increases the probability that a switch would occur in favor of the IFIs. This finding supports my hypothesis that the likelihood of voting in favor of the IFIs increases with greater PAC contributions from money center banks.

\footnotetext{
${ }^{16}$ See Stratmann (2002) for further information.
} 
In addition to changes in contributions from banks, changes in other variables appear to cause a shift in votes. In Model 1, the negative and significant sign on DW NOMINATE indicates that members who become more conservatism over time were less likely to support the IFIs. In Model 2, I control for changes in legislators' partisan affinity with the president with PRESIDENT'S PARTY, which takes the value of "1" when a legislator shares the party affiliation of the president, "0" otherwise. DW-NOMINATE is no longer significant in this model, but PRESIDENT'S PARTY is a positive and highly significant predictor of pro-IFI vote switches. Pseudo $\mathrm{R}^{2}$ also jumps to 0.25 in Model 2 from 0.14 in Model 1, indicating that the inclusion of PRESIDENT'S PARTY offers much greater explanatory power.

These results suggest that vote switching largely reflects changes in the chief executive, such that legislators are more likely to vote in favor of the IFIs when a president comes to office that shares their party affiliation. This partisan affinity may reflect the susceptibility of legislators to partisan presidential influence. When IFI bills are before Congress, they carry the imprimatur of the president; thus, legislators need to consider the consequences of voting with or against the president. ${ }^{17}$ Given the president's interest in seeing an IFI funding bill succeed, congressional voting may be influenced by presidential influence efforts. Chief executives command a number of resources that can helpful in building a partisan coalition in Congress. For example, Edwards (1989) examines the impact of presidential prestige and popularity, as well as electoral performance and coat-tail effects, on partisan coalition-building.

${ }^{17}$ As discussed above, executive branch officials negotiate the terms of funding increases with other IFI member governments before they seek authorization from Congress. By the time a funding bill is up for a vote, the president is squarely behind it. 


\section{Conclusion and Implications}

Given the presidential structure of government in the United States, any increase in U.S. contributions to the IFIs must be authorized by Congress. I have analyzed congressional roll-call voting on IFI funding and found that several political factors consistently influence the choices of legislators: their "ideology" with respect to the role of government in the economy, their party affiliations (and partisan affinity with the president), the share of campaign contributions they receive from banks that specialize in international lending and the share of high-skilled, proglobalization constituents residing in their districts. Conversely, my data do not support the Ricardo-Viner hypothesis that share of district workers in importing-competing or exporting industries correlate with voting behavior.

According to my estimates, economic conservatism is the most important source of antiIFI sentiment in the U.S. Congress, especially among Republican members. Conservative legislators view the IMF as a profligate bureaucracy that distorts incentives in international financial markets. To quote Newt Gingrich, the 1998 IMF quota increase was "typical liberal foreign policy...we're not turning over $\$ 18$ billion to a French Socialist [Michel Camdessus] to throw it away."18 Although extreme, Gingrich’s position is not uncommon in Congress. By my estimates, conservatism has a large, negative impact on the willingness to support the IFIs for members of both political parties, with Republican being almost twice as sensitive this ideological influence as Democrats.

${ }^{18}$ Camdessus was Managing Director of the IMF from 1987-2000. Speech before the Christian Coalition, September 18, 1998, Washington, DC. Cited in the New York Times, September 25, 1998. 
Does a more conservative Congress make it more difficult for the IFIs to increase their resources in the face of global challenges? Do U.S. officials at the IMF and World Bank consider congressional conservatism when they determine the size of a funding increase they will support? These are complicated questions because many factors--economic and political-shape IFI requests for funding increases. But historical evidence from Boughton (2001) suggests that there may be a relationship between the timing and size of IMF “quota increases" and the level of conservatism in Congress. ${ }^{19}$ Boughton (2001, 858-872) cites several cases where quota increase negotiations were influenced by Congress, as in the Seventh General Review, where the size of the quota increase was reduced to expedite congressional approval.

In Figure 1, I present somewhat more systematic evidence. The figure plots the percentage increase in IMF quotas (left axis) from all IMF General Reviews since 1950 against the average ideological position of the U.S. House of Representatives (right axis). ${ }^{20}$ DWNOMINATE, averaged for all members, proxies for ideology and ranges from -1 (very liberal) to 1 (very conservative). Four General Reviews at the IMF produced "no increase" in quotas: the First (1950), Second (1955), Tenth (1995), and Twelfth (2003). Note that these reviews occurred during periods when Congress was markedly conservative. Conversely, the seven large quota increases that occurred between 1960 and 1990 all came during liberal Congresses. The only exception is the Eleventh Review in 1998, in which a 45 percent increase occurred during a conservative Congress. But in that year, the Asian financial crisis put pressure on conservative

19 “Quota increases” is IMF nomenclature for a new funding plan.

${ }^{20}$ During a "General Review of Quotas," which must occur at least every five years, the IMF considers whether to increase funding requirements from member nations. I thank Mark Farrales for suggesting this figure. 
legislators to approve new resources for the IMF because they feared being held responsible if the world economy collapsed (Frankel and Roubini 2003). Had the conservative Congress refused to support the new appropriation for the IMF, and the world economy continued to spiral downward, conservatives might have paid the price in the next election. Further research might explore the extent to which conservatism in the U.S. Congress set limits on the timing and level of support the IMF and other IFIs can muster.

My finding on the impact of money center bank contributions should resonate with scholars that suppose banks are active in the politics of the IFIs (Stiglitz 2002, Bhagwati 2002). To my knowledge, this is the first analysis showing that representatives in Congress that are supported by banks are more likely to approve increased funding for the IFIs. I also established that the relationship is causal, such that changes in voting behavior follow changes in PAC contributions from banks. These findings extend the established research on the role of private financiers by showing that banks are active politically at multiple levels: on the specifics of IFI programs, they communicate directly with IFI officials and staff (Broz and Hawes 2006, Gould 2003, Oatley 2002, and Oatley and Yackee 2004). On matters of funding, they appear to work though Congress, which controls the purse strings.

Overall, my aim has been to specify the motivations of the political actors that formally decide levels of U.S. funding for the IFIs. I identified the personal, constituent, and special interest sources of legislator voting and tested to see if these factors find empirical support in the data. My results on personal ideology, constituency skill level, and campaign contributions from money center banks suggest that the United States funds the IFIs partly because liberal members of congress believe that the IFIs play necessary roles in global finance and economic 
development, partly because some constituents benefit from the IFIs' globalization efforts, and partly because international banks have a concentrated stake in IFI funding. 
Table 1: Congressional Roll-Call Votes On Funding the International Financial Institutions

\begin{tabular}{|c|c|c|c|c|c|}
\hline Number & HR 5262 & HR 7244 & $\begin{array}{l}\text { H.AMDT.306 } \\
\text { (HR 2957) }\end{array}$ & $\begin{array}{l}\text { H.AMDT.115 } \\
\text { (HR 2295) }\end{array}$ & $\begin{array}{l}\text { Motion to Instruct } \\
\text { Conferees } \\
\text { (HR 3579) }\end{array}$ \\
\hline Congress & $95^{\text {th }}$ & $96^{\text {th }}$ & $98^{\text {th }}$ & $103^{\text {rd }}$ & $105^{\text {th }}$ \\
\hline Date & 4/6/1977 & 9/18/1980 & 7/29/1983 & 6/17/1993 & 4/23/1998 \\
\hline Sponsor & Reuss (D-WI) & Neal (D-NC) & McCollum (R-FL) & Kasich (R-OH) & Obey (D-WI) \\
\hline Summary & $\begin{array}{l}\text { A bill to provide for } \\
\text { increased participation } \\
\text { by the United States in } \\
\text { the World Bank's } \\
\text { IBRD, IDA, and } \\
\text { International Finance } \\
\text { Corporation (IFC), as } \\
\text { well as the AsDB and } \\
\text { the Asian } \\
\text { Development Fund. }\end{array}$ & $\begin{array}{l}\text { To pass HR } \\
7244 \text {, to amend } \\
\text { the Bretton } \\
\text { Woods } \\
\text { Agreement Act } \\
\text { to authorize } \\
\text { consent to an } \\
\text { increase in the } \\
\text { US quota in the } \\
\text { IMF. }\end{array}$ & $\begin{array}{l}\text { To amend H.R. } 2957 \\
\text { to strike the language } \\
\text { authorizing the } \\
\text { Governor of the IMF } \\
\text { to consent to an } \\
\text { increase in the quota } \\
\text { of the United States. } \\
\text { [A "No" vote supports } \\
\text { the IMF]. }\end{array}$ & $\begin{array}{l}\text { An amendment to } \\
\text { eliminate the } \$ 55 \text { million } \\
\text { in funds appropriated in } \\
\text { the bill for the U.S. } \\
\text { capital contribution to the } \\
\text { World Bank and the } \\
\text { corresponding loan } \\
\text { authority such } \\
\text { contribution would } \\
\text { provide. [A “No" vote } \\
\text { supports the World Bank]. }\end{array}$ & $\begin{array}{l}\text { A motion to allow the } \\
\text { House and Senate to } \\
\text { pass identical spending } \\
\text { bills, providing the } \\
\text { IMF with } \$ 18 \text { billion } \\
\text { for a quota increase } \\
\text { and to establish the } \\
\text { New Arrangements to } \\
\text { Borrow (NAB). }\end{array}$ \\
\hline Result & Passed 194-156 & Passed 191-151 & Failed 182-227 & Failed 210-216 & Failed 186-222 \\
\hline $\begin{array}{l}\text { Partisan } \\
\text { split }\end{array}$ & $\begin{array}{l}\text { Dem: 149-87 } \\
\text { Rep: } 45-69\end{array}$ & $\begin{array}{l}\text { Dem: } 150-71 \\
\text { Rep: } 49-80\end{array}$ & $\begin{array}{l}\text { Dem: 90-158 } \\
\text { Rep: 92-69 }\end{array}$ & $\begin{array}{l}\text { Dem: 61-189 } \\
\text { Rep: } 148-23\end{array}$ & $\begin{array}{l}\text { Dem: 164-28 } \\
\text { Rep: 22-193 }\end{array}$ \\
\hline
\end{tabular}


Table 2: Vote Shares in the International Financial Institutions

\begin{tabular}{lrrrrrr}
\hline & $\begin{array}{c}\text { United } \\
\text { States }\end{array}$ & \multicolumn{1}{c}{ Japan } & Germany & $\begin{array}{c}\text { United } \\
\text { Kingdom }\end{array}$ & France & U.S. Veto \\
\hline & & & & & & \\
IMF & 16.89 & 6.02 & 5.88 & 4.86 & 4.86 & Yes \\
World Bank & 16.38 & 7.86 & 4.49 & 4.30 & 4.30 & Yes \\
IDB & 30.00 & 5.00 & 1.90 & 0.96 & 1.90 & Yes \\
AsDB & 12.76 & 12.76 & 3.75 & 1.92 & 2.16 & No \\
AfDB & 6.36 & 5.42 & 4.01 & 1.68 & 3.71 & No \\
EBRD & 10.10 & 8.61 & 8.61 & 8.61 & 8.61 & No \\
\hline
\end{tabular}

Note: The table gives the most recent vote shares (percent of total votes) for the Group of Five in the International Monetary Fund (IMF), the World Bank (IBRD), the Asian Development Bank (AsDB), the African Development Bank (AfDB), the European Bank for Reconstruction and Development (EBRD), and the Inter-American Development Bank (IDB). The final column indicates whether the United States has sufficient votes to veto important decisions that require a supermajority of votes. 
Table 3: Correlation Matrix

DW-Nominate Party College Bank PAC Net Imports Net Exports Med. Income

DW-Nominate 1.0000

Party $\quad 0.8721$

College $\quad 0.0922$

Bank PAC $\quad 0.0384$

Net Imports $\quad 0.0469$

Net Exports $\quad 0.0354$

Med. Income

0.1148

$\begin{array}{lll}1.0000 & & \\ 0.1620 & 1.0000 & \\ 0.0565 & 0.1869 & 1.0000 \\ 0.0063 & -0.3030 & -0.1037 \\ 0.0580 & 0.0501 & 0.0128 \\ 0.1535 & 0.7527 & 0.2778\end{array}$

1.0000

$0.3224 \quad 1.0000$

$-0.2465 \quad 0.0713$

1.0000 
Table 4: Probit Analyses of Voting on IFI Funding Legislation: Pooled Votes

\begin{tabular}{|c|c|c|c|c|c|}
\hline & $\begin{array}{c}(1) \\
5 \text { Votes }\end{array}$ & $\begin{array}{c}(2) \\
5 \text { Votes }\end{array}$ & $\begin{array}{c}(3) \\
4 \text { Votes }\end{array}$ & $\begin{array}{c}(4) \\
4 \text { Votes }\end{array}$ & $\begin{array}{c}(5) \\
4 \text { Votes }\end{array}$ \\
\hline DW-Nominate & $\begin{array}{r}-2.610 \\
(0.100)^{* * *}\end{array}$ & $\begin{array}{r}-4.853 \\
(0.290)^{* * *}\end{array}$ & $\begin{array}{r}-4.508 \\
(0.316)^{* * *}\end{array}$ & $\begin{array}{r}-4.473 \\
(0.320)^{* * *}\end{array}$ & $\begin{array}{r}-4.478 \\
(0.321)^{* * *}\end{array}$ \\
\hline Party & & $\begin{array}{r}1.670 \\
(0.165)^{* * *}\end{array}$ & $\begin{array}{r}1.395 \\
(0.185)^{* * *}\end{array}$ & $\begin{array}{r}1.310 \\
(0.188)^{* * *}\end{array}$ & $\begin{array}{r}1.285 \\
(0.187)^{* * *}\end{array}$ \\
\hline Bank PAC & & & $\begin{array}{r}0.029 \\
(0.007)^{* * *}\end{array}$ & $\begin{array}{r}0.026 \\
(0.007)^{* * *}\end{array}$ & $\begin{array}{r}0.034 \\
(0.008)^{* * *}\end{array}$ \\
\hline College & & & & $\begin{array}{r}1.651 \\
(0.557)^{* * *}\end{array}$ & $\begin{array}{r}4.526 \\
(0.847)^{* * *}\end{array}$ \\
\hline Net Imports & & & & $\begin{array}{r}0.478 \\
(0.501)\end{array}$ & $\begin{array}{r}0.435 \\
(0.505)\end{array}$ \\
\hline Net Exports & & & & $\begin{array}{r}1.777 \\
(1.480)\end{array}$ & $\begin{array}{r}2.138 \\
(1.481)\end{array}$ \\
\hline Median Income & & & & & $\begin{array}{r}-0.022 \\
(0.005)^{* * *}\end{array}$ \\
\hline Constant & $\begin{array}{r}-0.045 \\
(0.033)\end{array}$ & $\begin{array}{r}-0.810 \\
(0.080)^{* * *}\end{array}$ & $\begin{array}{r}-0.716 \\
(0.088)^{* * *}\end{array}$ & $\begin{array}{r}-1.122 \\
(0.160)^{* * *}\end{array}$ & $\begin{array}{r}-1.043 \\
(0.164)^{* * *}\end{array}$ \\
\hline $\begin{array}{l}\text { Observations } \\
\text { Log Likelihood } \\
\text { Pseudo R }\end{array}$ & $\begin{array}{r}1957 \\
-933.40 \\
0.31\end{array}$ & $\begin{array}{r}1955 \\
-856.66 \\
0.37\end{array}$ & $\begin{array}{r}1599 \\
-692.86 \\
0.37\end{array}$ & $\begin{array}{r}1584 \\
-676.87 \\
0.38\end{array}$ & $\begin{array}{r}1584 \\
-666.20 \\
0.39\end{array}$ \\
\hline
\end{tabular}

Notes: The dependant variable $=1$ if a member votes in favor of IFI funding, 0 otherwise ("nay" votes on H.AMDT 306 and H.AMDT 115 were coded as 1). Models 1 and 2 pool five votes: HR 5262, HR 7244, H.AMDT 306, H.AMDT 115, and the Motion on HR 3579. Models 3-5 exclude votes on HR 5262 because data on Bank PAC contributions are not available for this bill. 
Table 5: Substantive Effects

\begin{tabular}{lll}
\hline & Democrat & Republican \\
\hline DW-Nominate & $-0.32^{* * *}$ & $-0.60^{* * *}$ \\
College & $0.13^{* * *}$ & $0.09^{* * *}$ \\
Bank PAC & $.07^{* * *}$ & $0.05^{* * *}$ \\
Net Imports & 0.01 & 0.01 \\
Net Exports & 0.05 & 0.03 \\
\hline
\end{tabular}

* Significant at $10 \%$; ** at $5 \%$; *** at $1 \%$

Notes: Values represent the change in the predicted probability of voting in favor of IFI funding as each variable of interest is increased by one standard deviation over its mean, holding other variables at their means. For Democrats, PARTY is held to 0; for Republicans, PARTY is held to 1. Estimates are from the fullest models (Model 5) in Table 4. 


\begin{tabular}{|c|c|c|c|c|c|}
\hline & $\begin{array}{c}(1) \\
\text { HR 5262 } \\
(1977)\end{array}$ & $\begin{array}{c}(2) \\
\text { HR } 7244 \\
(1980)\end{array}$ & $\begin{array}{c}(3) \\
\text { H.AMDT } \\
306 \text { (1983) }\end{array}$ & $\begin{array}{c}(4) \\
\text { H.AMDT } \\
115 \text { (1993) }\end{array}$ & $\begin{array}{c}(5) \\
\text { Motion } \\
(1998)\end{array}$ \\
\hline DW-Nominate & $\begin{array}{r}-7.233 \\
(0.868)^{* * *}\end{array}$ & $\begin{array}{r}-4.930 \\
(0.818)^{* * * *}\end{array}$ & $\begin{array}{r}-4.430 \\
(0.513) * * *\end{array}$ & $\begin{array}{r}-4.072 \\
(0.695)^{* * *}\end{array}$ & $\begin{array}{r}-2.551 \\
(0.711)^{* * *}\end{array}$ \\
\hline Party & $\begin{array}{r}2.835 \\
(0.438)^{* * *}\end{array}$ & $\begin{array}{r}1.461 \\
(0.396)^{* * *}\end{array}$ & $\begin{array}{r}1.897 \\
(0.323)^{* * *}\end{array}$ & $\begin{array}{r}0.521 \\
(0.436)\end{array}$ & $\begin{array}{r}-0.640 \\
(0.521)\end{array}$ \\
\hline Bank PAC & & $\begin{array}{r}0.968 \\
(0.348)^{* * *}\end{array}$ & $\begin{array}{r}0.164 \\
(0.042)^{* * *}\end{array}$ & $\begin{array}{r}0.049 \\
(0.016)^{* * *}\end{array}$ & $\begin{array}{r}0.028 \\
(0.010)^{* * *}\end{array}$ \\
\hline College & $\begin{array}{r}8.228 \\
(4.119)^{* *}\end{array}$ & $\begin{array}{r}-1.530 \\
(2.910)\end{array}$ & $\begin{array}{r}3.989 \\
(1.885)^{* *}\end{array}$ & $\begin{array}{r}3.300 \\
(1.810)^{*}\end{array}$ & $\begin{array}{r}1.165 \\
(2.056)\end{array}$ \\
\hline Net Imports & $\begin{array}{r}-2.670 \\
(1.709)\end{array}$ & $\begin{array}{r}-2.154 \\
(1.055)^{* *}\end{array}$ & $\begin{array}{r}0.818 \\
(1.002)\end{array}$ & $\begin{array}{r}0.844 \\
(0.964)\end{array}$ & $\begin{array}{l}-1.085 \\
(1.160)\end{array}$ \\
\hline Net Exports & $\begin{array}{r}3.687 \\
(1.255)^{* * *}\end{array}$ & $\begin{array}{r}7.337 \\
(2.653)^{* * *}\end{array}$ & $\begin{array}{r}0.137 \\
(2.769)\end{array}$ & $\begin{array}{r}-2.222 \\
(3.102)\end{array}$ & $\begin{array}{r}0.857 \\
(2.296)\end{array}$ \\
\hline Median Income & $\begin{array}{r}-0.023 \\
(0.072)\end{array}$ & $\begin{array}{r}0.134 \\
(0.062)^{* *}\end{array}$ & $\begin{array}{r}-0.005 \\
(0.030)\end{array}$ & $\begin{array}{r}0.001 \\
(0.016)\end{array}$ & $\begin{array}{r}0.013 \\
(0.016)\end{array}$ \\
\hline Constant & $\begin{array}{r}-2.558 \\
(0.505)^{* * *}\end{array}$ & $\begin{array}{r}-1.777 \\
(0.427)^{* * *}\end{array}$ & $\begin{array}{r}-1.597 \\
(0.445)^{* * *}\end{array}$ & $\begin{array}{r}-1.243 \\
(0.392)^{* * *}\end{array}$ & $\begin{array}{r}-0.467 \\
(0.438)\end{array}$ \\
\hline $\begin{array}{l}\text { Observations } \\
\text { Log Likelihood } \\
\text { Pseudo }{ }^{2}\end{array}$ & $\begin{array}{r}340 \\
-130.14 \\
0.45\end{array}$ & $\begin{array}{r}341 \\
-140.63 \\
0.40\end{array}$ & $\begin{array}{r}412 \\
-199.56 \\
0.29\end{array}$ & $\begin{array}{r}426 \\
-155.54 \\
0.47\end{array}$ & $\begin{array}{r}405 \\
-126.84 \\
0.55\end{array}$ \\
\hline
\end{tabular}

Notes: The dependant variable $=1$ if a member votes in favor of IFI funding, 0 otherwise ("nay" votes on H.AMDT 306 and H.AMDT 115 were coded as 1). 
Table 7: Conditional (Fixed Effects) Logit Analysis of Changes in Voting Behavior

(1) (2)

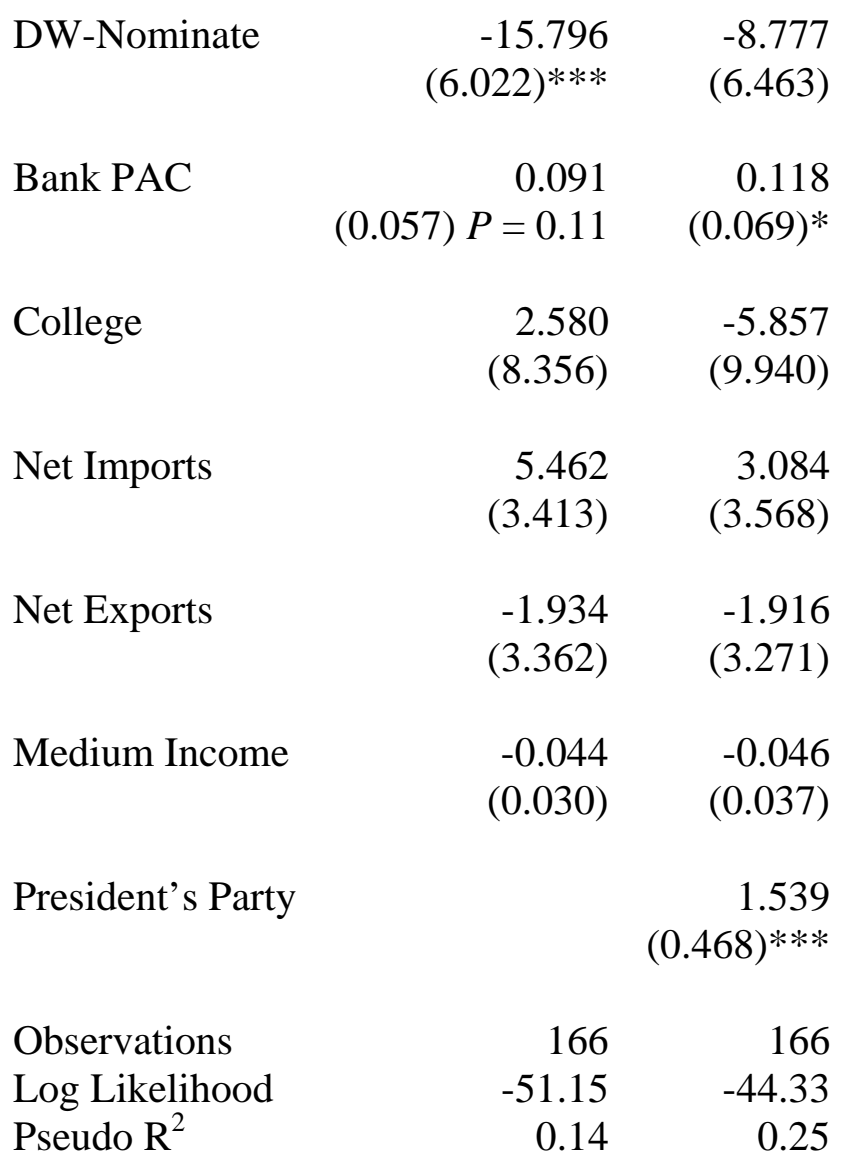

Standard errors in parentheses * significant at $10 \%$; ** at $5 \%$; *** at $1 \%$

Notes: The Conditional Logit model exploits the time-series nature of the data (votes on similar bills over time) to explore the relationship between BANK PAC contributions-and voting. The variation to be explained is the 166 cases in which individual legislators switched their votes on IFI funding bills over time. A dependent variable value of " 1 " indicates that a legislator switched from "nay" to "yea” across votes; "0" indicates a "yea” to "nay" switch. BANK PAC reflects contribution levels from the previous electoral cycle; DW-NOMINATE and COLLEGE reflect values for the current year. PARTY is omitted because there is no within-legislator variance in party affiliation over time. PRESIDENT'S PARTY equals “ 1 ” if a legislator shares the party affiliation of the president, "0” otherwise. 
Figure 1: Average “Ideology” of the U.S. House of Representative and IMF Quota Increases, 1950-2004

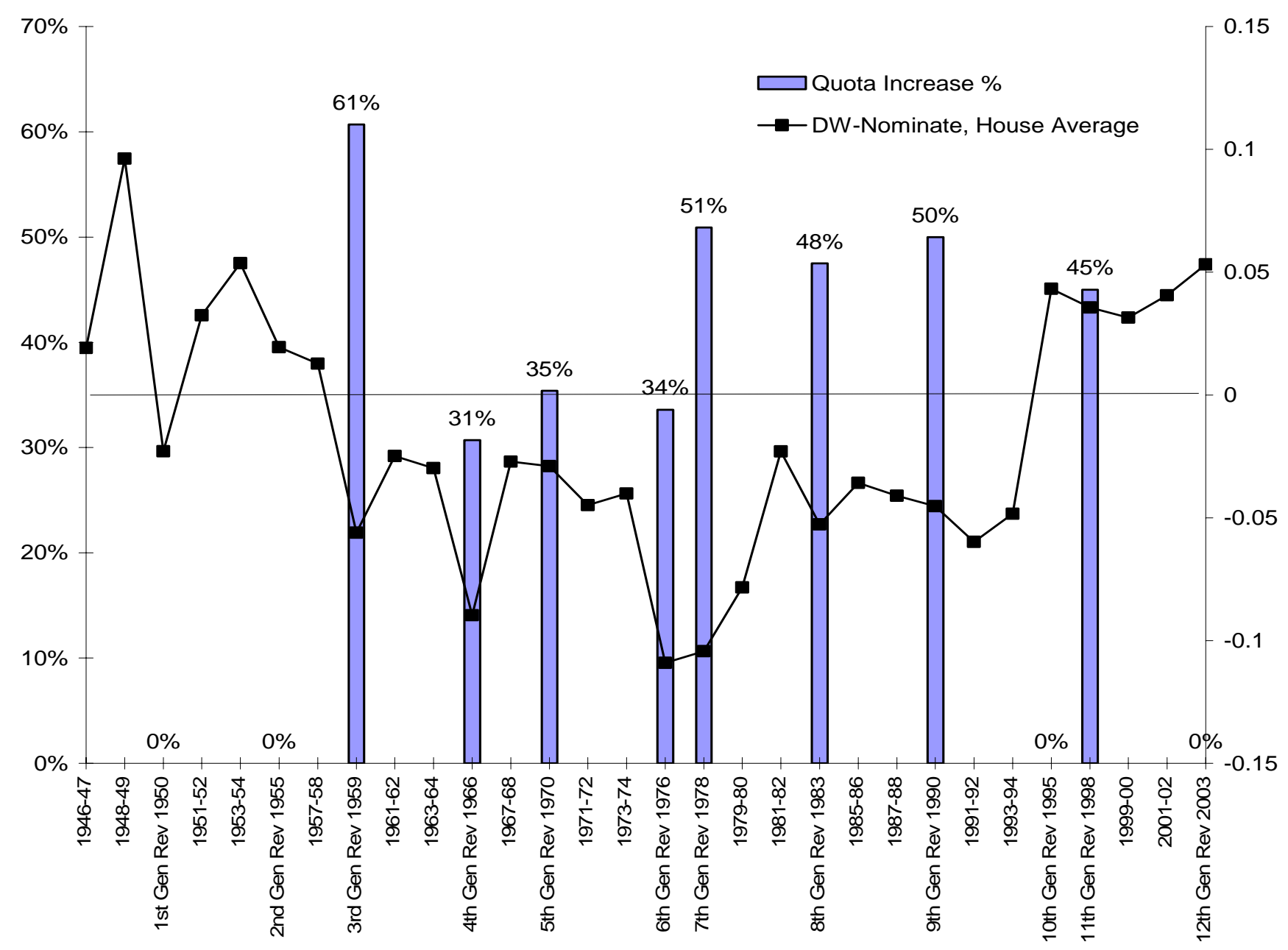

Notes: DW-NOMINATE (right scale) is the average ideological score of the House of Representatives on the broad issue of government intervention in the economy. Higher values denote a more conservative ideology. IMF quota increases (left scale) are quota increases approved by the IMF’s Board of Governors during a General Review of Quotas. 


\section{References}

Adler, E. Scott. "Congressional District Data File, [congressional term]." University of Colorado, Boulder, CO.

Ansolabehere, Stephen, James M. Snyder, Jr. and Charles Stewart III. 2001. "The Effects of Party and Preferences on Congressional Roll-Call Voting.” Legislative Studies Quarterly 26 (4): 533-572

Ansolabehere, Stephen, John de Figueiredo, and James M. Snyder, Jr. 2003. "Why Is There So Little Money in U.S. Politics?” Journal of Economic Perspectives 17(1):105- 30.

Arnold, R. Douglas. 1992. The Logic of Congressional Action. New Haven: Yale University Press.

Bailey, Michael. 2001. "Quiet Influence: The Representation of Diffuse Interests on Trade Policy, 1983- 1994.” Legislative Studies Quarterly (February): 45-80.

Bailey, Michael and David Brady. 1998. "Heterogeneity and Representation: The Senate and Free Trade.” American Journal of Political Science 42: 524-544.

Baldwin, Robert E. and Christopher S. Magee. 2000. Congressional Trade Votes: From NAFTA Approval to Fast-Track Defeat. Washington DC: Institute for International Economics.

Bhagwati, Jagdish N. 2002. The Wind of the Hundred Days: How Washington Mismanaged Globalization. MIT Press.

Bird, Graham. 1996. "The International Monetary Fund and Developing Countries: A Review of the Evidence and Policy Options,” International Organization 50 (summer): 477-511.

Boughton, James M. 2001. Silent Revolution: The International Monetary Fund, 1979-1989. Washington: International Monetary Fund.

Blomberg, Brock and J. Lawrence Broz. 2007. "The Political Economy of IMF Voting Power." Unpublished working paper.

Broz, J. Lawrence. 2005. "Congressional Politics of International Financial Rescues." American Journal of Political Science 49, 3 (July): 479-496.

Broz, J. Lawrence and Michael Brewster Hawes. 2006. "Congressional Politics of Financing the International Monetary Fund.” International Organization 60, 2 (spring): 367-399.

Bulow, Jeremy and Kenneth Rogoff. 1990. "Cleaning Up Third-World Debt Without Getting Taken To the Cleaners.” Journal of Economic Perspectives 4 (winter):31-42.

Campa, José and Linda S. Goldberg, 1999. "The Evolving External Orientation of Manufacturing Industries: A Profile of Four Countries.” The Federal Reserve Bank of New York Economic Policy Review (July): 53-81.

Clausen, Aage. R. 1973. How Congressmen Decide: A Policy Focus. New York: St. Martin’s

Cox Gary W. and Mathew D. McCubbins. 2005. Setting the Agenda: Responsible Party Government in the House of Representatives. New York: Cambridge University Press.

Demirguc-Kunt, Asli and Harry Huizinga. 1993. "Official Credits to Developing Countries: Implicit Transfers to the Banks.” Journal of Money, Credit and Banking 25, 3: 430-44.

Denzau, Arthur and Michael Munger. 1986. "Legislators and Interest Groups: How Unorganized Interests Get Represented.” American Political Science Review (80): 89-106.

Edwards III, George C. 1989. At the Margins: Presidential Leadership of Congress. New Haven: Yale University Press.

Frankel, Jeffrey and Nouriel Roubini. 2003. "The Role of Industrial Country Policies in Emerging Market Crises." In Economic and Financial Crises in Emerging Market 
Economies, edited by Martin S. Feldstein, pp. 155-201, Chicago: University of Chicago Press.

Froman, Jr., Lewis A. 1963. "Inter-Party Constituency Differences and Congressional Voting Behavior.” The American Political Science Review. 57 (1):57-61.

Gould, Erica R. 2003. "Money Talks: Supplementary Financiers and International Monetary Fund Conditionality.” International Organization 57 (3): 551-86.

Hall, Richard L. and Frank W. Wayman. 1990. "Buying Time: Moneyed Interests and the Mobilization of Bias in Congressional Committees." American Political Science Review 84: 797-820.

Haskel, Jonathan E. and Matthew J. Slaughter. 2000. "Have Falling Tariffs and Transportation Costs Raised US Wage Inequality?” NBER Working Paper No. 7539. Cambridge, MA: National Bureau of Economic Research.

Horsefield, J. Keith. 1969. The International Monetary Fund, 1945-1965: Twenty Years of International Monetary Cooperation. Vol. 1: Chronicle. Washington: International Monetary Fund..

King, Gary, Michael Tomz, and Jason Wittenberg. 2000. "Making the Most of Statistical Analyses: Improving Interpretation and Presentation." American Journal of Political Science 44, 2 (March): 341-55.

Kroszner, Randall S and Thomas Stratmann. 1998. "Interest-Group Competition and the Organization of Congress: Theory and Evidence from Financial Services' Political Action Committees." American Economic Review 88, 5: 1163-87.

Krueger, Alan. B. 1996. "Observations on International Labor Standards and Trade." NBER Working Paper No. 5632. Cambridge, MA: National Bureau of Economic Research.

Locke, Mary. 2000. "Funding the IMF: The Debate in the U.S. Congress." Finance and Development 37, 3 (September).

Mayda, Anna Maria, and Dani Rodrik. 2005. "Why Are Some Individuals (and Countries) More Protectionist than Others?" European Economic Review (forthcoming).

Meltzer, Allan H. 1998. “Asian Problems and The IMF.” Cato Journal 17, 3(winter): 267-74.

Miller, Warren and Donald Stokes. 1963. "Constituency Influence in Congress." American Political Science Review 57: 45-56.

Mundell, Robert A. 1957. "International Trade and Factor Mobility." American Economic Review 47 (June): 321-35.

Oatley, Thomas. 2002. "Commercial Banks and the International Monetary Fund: An Empirical Analysis.” Mimeo. University of North Carolina at Chapel Hill.

Oatley, Thomas and Jason Yackee. 2004. "American Interests and IMF Lending." International Politics 41, 3: 415-429.

O'Rourke, Kevin. 2003. "Heckscher-Ohlin Theory and Individual Attitudes Towards Globalization." NBER Working Paper No. 9872. Cambridge, MA: National Bureau of Economic Research.

Poole, Keith T. and Howard Rosenthal. 1997. Congress: A Political-Economic History of Roll Call Voting. New York: Oxford University Press.

Rogoff, Kenneth. 1999. "International Institutions for Reducing Global Financial Instability." Journal of Economic Perspectives 13, 4 (Fall):21-42.

Sanford, Jonathan E. 2005. "International Financial Institutions: Funding U.S. Participation.” CRS Report for Congress RS22134. Congressional Research Service, The Library of Congress 
Scheve, Kenneth F. and Matthew J. Slaughter. 2001. "What Determines Individual Trade-Policy Preferences?” Journal of International Economics (August) 54, 267-92.

Stolper, Wolfgang and Paul A. Samuelson. 1941. "Protection and Real Wages." Review of Economic Studies 9: 58-73.

Stiglitz, Joseph. 2002. Globalization and Its Discontents. Norton, W. W. \& Company.

Stratmann, Thomas. 2002. Can Special Interests Buy Congressional Votes? Evidence from Financial Services Legislation. Journal of Law and Economics 45 (2):345-73.

Tomz, Michael, Jason Wittenberg, and Gary King. 1998. "CLARIFY: Software for Interpreting and Presenting Statistical Results." Version 1.2. Cambridge MA: Harvard University.

U.S. Congress. 1981. House. Committee on Appropriations. Subcommittee on Foreign Operations and Related Agencies, Foreign Assistance and Related Programs Appropriations for 1982: Hearings before a Subcommittee of the Committee on Appropriations, 97th Congress, First Session (Washington, DC: GPO).

Wood, Adrian. 1994. North-South Trade, Employment, and Inequality: Changing Fortunes in a Skill-Driven World. Oxford: Clarendon Press.

Woods, Ngaire. 2003. "The United States and the International Financial Institutions: Power and Influence within the World Bank and the IMF.” In Rosemary Foot, S. Neil MacFarlane, and Michael Mastanduno, eds. US Hegemony and International Organizations. London: Oxford University Press.

Woods, Ngaire. 2006. The Globalizers: The IMF, the World Bank and Their Borrowers. New York: Cornell University Press. 


\section{Data Appendix}

BANK PAC: Campaign contributions from money center bank political action committees to candidates in the previous electoral cycle, divided by 1,000 (contemporaneous 1979-80 data were used HR 7244). Money center banks are identified by the Federal Financial Institutions Examination Council, Country Exposure Lending Survey (various years). In the 1979-80 cycle, the FFIEC list includes Bankers Trust, Chase Manhattan, Chemical Bank, Citicorp, Continental Illinois, First Chicago, Manufacturers Hanover, and J.P. Morgan \& Co. In the 1981-82 cycle, BankAmerica Corp joins the list. By the 1996-97 cycle, consolidations and takeovers had reduced the list of money center banks to Bank of America, Bankers Trust, Chase Manhattan, Citicorp, First Chicago, and J. P. Morgan \& Co. Contributions from these banks' political action committee to candidates are from the Federal Election Commission.

COLLEGE: Share of district population, aged 25 and up, with four or more years of college. Congressional Districts of the United States, U.S., Bureau of the Census.

DW-NOMINATE: The first dimension of the DW-Nominate score, capturing a member's ideological position on government intervention in the economy. DWNominate estimates the position of each legislator, using roll call voting and scaling techniques. Scores range from -1 to 1 , with higher values denoting a more conservative ideology. McCarty, Poole, and Rosenthal (1997).

MEDIAN INCOME: Median district household income, divided by 1,000. Source: Adler, E. Scott. “Congressional District Data File, [congressional term].” University of Colorado, Boulder, CO.

NET EXPORTS: Percent district population aged 16 years and over employed in net export industries. Net export industries are two-digit SIC manufacturing sectors where the ratio of revenues from exports to total industry revenue is greater than the ratio of imports to consumption. These ratios are provided by Campa and Goldberg (1997) for three time periods: 1975, 1985, 1995. I used the sample closest to each vote to assemble the data. In 1975, net export industries were Tobacco 21, Textiles 22, Lumber 24, Printing 27, Chemicals 28, Fabricated metals 34, Industrial machinery 35, Electronic equipment 36, Transportation equipment 37, and Instruments 38. In 1985, net export industries were Tobacco 21, Chemicals 28, Industrial machinery 35, and Instruments 38. In 1995, net export industries were Food 20, Tobacco 21, Printing 27, Chemicals 28, and Instruments 38. The source for sectoral employment is the County Business Patterns, Bureau of the Census. County-level employment data was aggregated up to the congressional district level using the following procedure: If a county contains more than one congressional district within its borders, the number of workers from an industry who are in each district is estimated by using the fraction of the county's population residing in each district. For example, if 10 percent of a county's population lives in a district, that district receives 10 percent of the county's workers in each industry. I obtained the geographic information from the MABLE '98/Geocorr v3.0 Geographic Correspondence Engine [http://plue.sedac.ciesin.org/plue/geocorr]. 
NET IMPORTS: Percent district population aged 16 years and over employed in net import industries. Net import industries are two-digit SIC manufacturing sectors where the ratio of imports to consumption is greater than the ratio of revenues from exports to total industry revenue. These ratios are provided by Campa and Goldberg (1997) for three time periods 1975, 1985, 1995. I used the sample closest to each vote. In 1975, net import industries were Food 20, Apparel 23, Furniture 25, Petroleum 29, Rubber 30, Leather 31, Primary metals 33, and Other manufacturing 39. In 1985, net import industries were Food 20, Textiles 22, Apparel 23, Lumber 24, Furniture 25, Paper 26, Petroleum 29, Rubber 30, Leather 31, Stone, Clay and Glass 32, Primary metals 33, Fabricated metals 34, Electronic goods 36, Transportation equipment 37, and Other manufacturing 39. In 1995, net import industries were Textiles 22, Apparel 23, Lumber 24, Furniture 25, Paper 26, Petroleum 29, Rubber 30, Leather 31, Stone, Clay and Glass 32, Primary metals 33, Fabricated metals 34, Industrial Machinery 35, Electronic goods 36, Transportation equipment 37, Instruments 38, and Other manufacturing 39. Sectoral employment is from County Business Patterns, Bureau of the Census. See "Net Imports" for the concordance procedure.

PARTY: Denotes the political party affiliation of a legislator, where $1=$ Republican and $0=$ Democrat.

PRESIDENT'S PARTY: Denotes whether a member is of the same political party as the current president, where, 1 = same party, 0 otherwise 